\title{
INDEX to Volume 19 (2001)
}

\section{Articles}

GORDON, Philip H. and MEUNIER, Sophie. Globalization and French Cultural Identity (Vol. 19, No. 1, p. 22)

GRUNBERG, Gérard. Les élections locales françaises de mars 2001: un échec pour la majorité (Vol. 19, No. 3, p. 17)

GUELDRY, Michel. La présidence française du Conseil de l'Union européenne (Vol. 19, No. 2, p. 1)

HOWARD, Dick. From Republican Political Culture to Republican Democracy: The Benefits and Burdens of History (Vol. 19, No. 3, p. 60)

KUISEL, Richard. The Gallic Rooster Crows Again: The Paradox of French AntiAmericanism (Vol. 19, No. 3, p. 1)

LAMONT, Michèle. Immigration and the Salience of Racial Boundaries among French Workers (Vol. 19, No. 1, p. 1)

LIEBERMAN, Robert. A Tale of Two Countries: The Politics of Color-Blindedness in France and the United States (Vol. 19, No. 3, p. 32)

\section{Dossier: Political Corruption}

DUPIN, Éric. La Corruption politique: un mal français (Vol. 19, No. 1, p. 42)

JANKOWSKI, Paul. Méry de Paris (Vol. 19, No. 1, p. 61)

LASCOUMES, Pierre. Change and Resistance in the Fight Against Corruption (Vol. 19, No. 1, p. 49)

\section{Dossier: Challenging the Social Boundaries in Post-Revolutionary FRANCE}

COSSART, Paula. Conjugaliser l'adultère : la liaison de deux amants parisiens, Adèle Schunck et Aimé Guyet de Frenex (1824-1849) (Vol. 19, No. 2, p. 43)

MAZA, Sarah. Uniforms: The Social Imaginary in Balzac's La Cousine Bette (Vol. 19, No. 2, p. 21) 


\section{Dossier: New Museums—Limits and Possibilities}

DE BAECQUE, Antoine. Pour une histoire visuelle du vingtième siècle : le Musée du cinéma Henri Langlois et les historiens (Vol. 19, No. 2, p. 64)

DEBARY, Octave. Mémoire oublieuse (Vol. 19, No. 2, p. 102)

DIAS, Nélia. Esquisse ethnographique d'un projet : le Musée du Quai Branly (Vol. 19, No. 2, p. 82)

\section{Dossier: Revisiting the Torture of the Algerian War}

COHEN, William B. The Sudden Memory of Torture: The Algerian War in French Discourse, 2000-2001 (Vol. 19, No. 3, p. 82)

DELACAMPAGNE, Christian. Torturante Mémoire (Vol. 19, No. 3, p. 95)

\section{Forum: La GUERRE DES ÉCRIVAINS (1940-1953), Gisèle SAPIRO}

JEANPIERRE, Laurent. Politiques de l'écrivain ou politiques de l'écriture ? (Vol. 19, No. 1, p. 70)

SAPIRO, Gisèle. Réponse (Vol. 19, No. 1, p. 88)

UNGAR, Steven. Vichy: Beyond the Syndrome Syndrome? (Vol. 19, No. 1, p. 82)

\section{Review Essays}

BOULLE, Pierre. French Slavery and Modern Political Culture. Review of "There Are No Slaves in France": The Political Culture of Race and Slavery in the Ancien Régime by Sue Peabody and Les Esclaves de la République. L'histoire oubliée de la première émancipation, 1789-1794 by Laurent Dubois (Vol. 19, No. 1, p. 98)

SIBALIS, Michael. Homosexuality in France (Vol. 19, No. 3, p. 108)

SCHWARTZWALD, ROBERT. Dangerous Liaisons in 1940s Quebec: Vichy or la France libre. Review of Le Québec entre Pétain et de Gaulle: Vichy, la France libre et les Canadiens français 1940-1945 by Eric Amyot (Vol. 19, No. 1, p. 105)

ZDATNY, Steven. War and Liberation: Histories from Below. Review of The Expectation of Justice: France, 1944-1946 by Megan Koreman and Between Resistance and Collaboration: Popular Protest in Northern France, 1940-45 by Lynne Taylor (Vol. 19, No. 1, p. 112)

\section{Book Reviews}

ALDRICH, Robert. Monsters and Revolutionaries: Colonial Family Romance and Métissage by Françoise Vergès and Children of the French Empire: Miscegenation and Colonial Society in French West Africa 1895-1960 by Owen White (Vol. 19, No. 1, p. 122)

ANSELL, Christopher K. Comprendre les évolutions électorales: la théorie des réalignements revisitée by Pierre Martin (Vol. 19, No. 1, p. 134)

ARMUS, Seth. The Collaborator: The Trial and Execution of Robert Brasillach by Alice Kaplan (Vol. 19, No. 2, p. 129) 
BAUDELOT, Christian. L'invention de l'«illettrisme», rhétorique publique, éthique et stigmates by Bernard Lahire (Vol. 19, No. 3, p. 143)

BÉNATOUÏL, Thomas. Comparer l'incomparable by Marcel Detienne (Vol. 19, No. 2, p. 135)

BERLANSTEIN, Lenard R. The Modernist Enterprise: French Elites and the Threat of Modernity, 1900-1940 by Marjorie A. Beale (Vol. 19, No. 2, p. 120)

COVINGTON, Elizabeth. The New Biography: Performing Femininity in NineteenthCentury France by Jo Burr Margadant (Vol. 19, No. 3, p. 120)

DELACAMPAGNE, Christian. Émigré New York: French Intellectuals in Wartime Manhattan, 1940-1944 by Jeffrey Mehlman (Vol. 19, No. 1, p. 128)

DEVIGNE, Michel and MULHMANN, David. Paris, ville invisible by Bruno Latour and Émilie Hermant (Vol. 19, No. 1, p. 138)

DOWNS, Laura Lee. Ouvrières parisiennes: marchés du travail et trajectoires professionnelles au vingtième siècle by Catherine Omnès (Vol. 19, No. 2, p. 121)

FORD, Caroline. France and the Cult of the Sacred Heart: An Epic for Modern Times by Raymond Jonas (Vol. 19, No. 3, p. 123)

FROST, Robert L. Retour sur la condition ouvrière: enquête aux usines Peugeot de SochauxMontbéliard, by Stéphane Beaud and Michel Pialoux (Vol. 19, No. 1, p. 130)

LEWIS, Mary D. The Colonial Unconscious: Race and Culture in Interwar France by Elizabeth Ezra (Vol. 19, No. 2, p. 126)

LORCIN, Patricia M.E. Journal 1955-1962: Reflections on the French-Algerian War by Mouloud Feraoun (Vol. 19, No. 3, p. 137)

MILLER, Michael. The Construction of Memory in Interwar France by Daniel J. Sherman (Vol. 19, No. 1, p. 124)

MOLLENKOPF, John. The Social Control of Cities: A Comparative Perspective by Sophie Body-Gendrot (Vol. 19, No. 2, p. 137)

MORGAN, Kimberley J. Confessions of an Interest Group: The Catholic Church and Political Parties in Europe by Carolyn Warner (Vol. 19, No. 3, p. 131)

OFFEN, Karen. The Rise of Professional Women in France: Gender and Public Administration since 1830 by Linda L. Clark (Vol. 19, No. 3, p. 127)

REARICK, Charles. Mona Lisa's Escort: André Malraux and the Reinvention of French Culture by Herman Lebovics (Vol. 19, No. 3, p. 140)

REDDY, William M. Politics and Theater: The Crisis of Legitimacy in Restoration France, 1815-1830 by Sheryl Kroen (Vol. 19, No. 2, p. 114)

ROUSSO, Henry. Vichy's Afterlife: History and Counterhistory in Postwar France by Richard J. Golsan (Vol. 19, No. 3, p. 134)

SILVERMAN, Willa Z. Pulp Surrealism: Insolent Popular Culture in Early TwentiethCentury Paris by Robin Walz (Vol. 19, No. 2, p. 117)

SMITH, W. Rand. Tocqueville's Revenge: State, Society, and Economy in Contemporary France by Jonah D. Levy (Vol. 19, No. 2, p. 139)

STONE, Judith. Pluralist Thought and the State in Britain and France, 1900-25 by Cécile Laborde (Vol. 19, No. 3, p. 125)

ULIN, Robert C. Crafting the Culture and History of French Chocolate by Susan J. Terrio (Vol. 19, No. 2, p. 132)

WILLIAMS, Rosalind. Apartment Stories: City and Home in Nineteenth-Century Paris and London by Sharon Marcus (Vol. 19, No. 1, p. 120) 


\section{INDEX OF BOOKS REVIEWED}

AMYOT, Éric. Le Québec entre Pétain et de Gaulle: Vichy, la France libre et les Canadiens français 1940-1945 reviewed by Robert Schwartzwald (Vol. 19, No. 1, p. 105)

BEALE, Marjorie A. The Modernist Enterprise: French Elites and the Threat of Modernity, 1900-1940 reviewed by Lenard R. Berlanstein (Vol. 19, No. 2, p. 120)

BEAUD, Stéphane and PIALOUX, Michel. Retour sur la condition ouvrière: enquête aux usines Peugeot de Sochaux-Montbéliard reviewed by Robert L. Frost (Vol. 19, No. 1, p. 130)

BODY-GENDROT, Sophie. The Social Control of Cities: A Comparative Perspective reviewed by John Mollenkopf (Vol. 19, No. 2, p. 137)

CLARK, Linda L. The Rise of Professional Women in France: Gender and Public Administration since 1830 reviewed by Karen Offen (Vol. 19, No. 3, p. 127)

DETIENNE, Marcel. Comparer l'incomparable reviewed by Thomas Bénatouil (Vol. 19, No. 2, p. 135)

DUBOIS, Laurent. Les Esclaves de la République. L'histoire oubliée de la première émancipation, 1789-1794 reviewed by Pierre Boulle (Vol. 19, No. 1, p. 98)

EZRA, Elizabeth. The Colonial Unconscious: Race and Culture in Interwar France reviewed by Mary D. Lewis (Vol. 19, No. 2, p. 126)

FERAOUN, Mouloud. Journal 1955-1963: Reflections on the French-Algerian War reviewed by Patricia M. Lorcin (Vol. 19, No. 3, p. 137)

GOLSAN, Richard J. Vichy's Afterlife: History and Counterhistory in Postwar France reviewed by Henry Rousso (Vol. 19, No. 3, p. 134)

JONAS, Raymond. France and the Cult of the Sacred Heart: An Epic for Modern Times reviewed by Caroline Ford (Vol. 19, No. 3, p. 123)

KAPLAN, Alice. The Collaborator: The Trial and Execution of Robert Brasillach reviewed by Seth Armus (Vol. 19, No. 2, p. 129)

KOREMAN, Megan. The Expectation of Justice: France, 1944-1946 reviewed by Steven Zdatny (Vol. 19, No. 1, p. 112)

KROEN, Sheryl. Politics and Theater: The Crisis of Legitimacy in Restoration France, 18151830 reviewed by William M. Reddy (Vol. 19, No. 2, p. 114)

LABORDE, Cécile. Pluralist Thought and the State in Britain and France, 1900-25 reviewed by Judith F. Stone (Vol. 19, No. 3, p. 125)

LAHIRE, Bernard. L'Invention de l'«illettrisme», rhétorique publique, éthique et stigmates reviewed by Christian Baudelot (Vol. 19, No. 3, p. 143)

LATOUR, Bruno and HERMANT, Émilie. Paris, ville invisible reviewed by Michel Devigne and David Mulhmann (Vol. 19, No. 1, p. 138)

LEBOVICS, Herman. Mona Lisa's Escort: André Malraux and the Reinvention of French Culture reviewed by Charles Rearick (Vol. 19, No. 3, p. 140)

LEVY, Jonah D. Tocqueville's Revenge: State, Society, and Economy in Contemporary France reviewed by W. Rand Smith (Vol. 19, No. 2, p. 139)

MARCUS, Sharon. Apartment Stories: City and Home in Nineteenth-Century Paris and London reviewed by Rosalind Williams (Vol. 19, No. 1, p. 120)

MARGADANT, Jo. Burr, The New Biography: Performing Femininity in Nineteenth-Century France reviewed by Elizabeth Covington (Vol. 19, No. 3, p. 120)

MARTIN, Pierre. Comprendre les évolutions électorales: la théorie des réalignements revisitée reviewed by Christopher K. Ansell (Vol. 19, No. 1, p. 134)

MEHLMAN, Jeffrey. Émigré New York: French Intellectuals in Wartime Manhattan, 19401944 reviewed by Christian Delacampagne (Vol. 19, No. 1, p. 128)

OMNÈS, Catherine. Ouvrières parisiennes: marchés du travail et trajectoires professionnelles au vingtième siècle reviewed by Laura Lee Downs (Vol. 19, No. 2, p. 121) 
PEABODY, Sue. "There Are No Slaves in France": The Political Culture of Race and Slavery in the Ancien Régime reviewed by Pierre Boulle (Vol. 19, No. 1, p. 98)

SHERMAN, Daniel J. The Construction of Memory in Interwar France reviewed by Michael Miller (Vol. 19, No. 1, p. 124)

TERRIO, Susan J. Crafting the Culture and History of French Chocolate reviewed by Robert C. Ulin (Vol. 19, No. 2, p. 132)

TAYLOR, Lynne. Between Resistance and Collaboration: Popular Protest in Northern France, 1940-45 reviewed by Steven Zdatny (Vol. 19, No. 1, p. 112)

VERGÈS, Françoise. Monsters and Revolutionaries: Colonial Family Romance and Métissage reviewed by Robert Aldrich (Vol. 19, No. 1, p. 122)

WALZ, Robin. Pulp Surrealism: Insolent Popular Culture in Early Twentieth-Century Paris reviewed by Willa Z. Silverman (Vol. 19, No. 2, p. 117)

WARNER, Carolyn. Confessions of an Interest Group: The Catholic Church and Political Parties in Europe reviewed by Kimberly J. Morgan (Vol. 19, No. 3, p. 131)

WHITE, Owen. Children of the French Empire: Miscegenation and Colonial Society in French West Africa 1895-1960 reviewed by Robert Aldrich (Vol. 19, No. 1, p. 122) 